\title{
Food industry waste composting in a rotational reactor
}

\author{
Przemysław Tronina, Fabiola Bubel \\ Poltegor-Institute, Institute of Surface Mining, Wrocław, Poland, e-mail: fabiola.bubel@igo.wroc.pl
}

\begin{abstract}
The permanently rising costs of food industry waste management create a real necessity for searching for new economical and environmentally friendly technologies with which such waste can be utilized. The purpose of this study was an evaluation of waste composting using rotational reactor technology with further use of the resultant product as a fertilizer. In order to conduct the research, a rotational reactor was designed and constructed. For the composting process, such waste materials as meat and bone pulp, past its sell-by date dairy and bakery products, sawdust, poultry and cattle manure, were used. The composition of the composted masses was chosen so that their approximate $\mathrm{C}: \mathrm{N}: \mathrm{P}$ proportions and consistency were appropriate for the growth of biodegradating micro-organisms. The efficiency of the presented technology was evaluated based on the inactivation of selected strains of bacteria and the eggs of invasive parasites. The products obtained were tested by the Institute of Soil Science and Plant Cultivation in Puławy with regard to its possible environmental usage.
\end{abstract}

Keywords: food wastes processing, organic fertilizer, compost.

Presented at VII Conference Wasteless Technologies and Waste Management in Chemical Industry and Agriculture, Międzyzdroje, 12 - 15 June, 2007.

\section{INTRODUCTION}

Food industry waste management has become an increasingly important issue due to rising costs of utilization. Composting, in view of its low costs, has recently become a widely used technique for organic and organicmineral waste processing. Composting is the biodegradation of organic matter by micro-organisms. Regardless of the materials used for composting, optimal conditions for microbe growth need to be created. It includes such parameters as temperature, $\mathrm{pH}$, humidity and appropriate carbon to nitrogen ratio $(\mathrm{C}: \mathrm{N})^{\mathbf{1}}$.

Unfortunately, most of the wastes generated by the food industry are not utilized. For example, of animal raw materials food processing industry waste, only about $37 \%$ is further processed, while $30 \%$ becomes sewage and the remaining $33 \%$ is stored ${ }^{2}$. However, storing this kind of waste may cause a serious sanitary and odour-forming threat by emitting hydrogen sulphide, aldehydes, organic acids or ammonia. Therefore, there is a significant need for a market to develop the economically justified food industry waste utilization technology that meets legal requirements in terms of environmental protection.
The aim of this study was to evaluate the efficiency of composting in rotational reactor technology, based on the inactivation of selected strains of bacteria and eggs of invasive parasites ${ }^{3}$. Also, the composting batch was estimated in respect of the used materials and proportions. The resultant fertilizer was tested chemically and microbiologically by the Institute of Soil Science and Plant Cultivation in Puławy, Poland, in respect of its possible environmental usage and whether or not it met the legal requirements demanded for organic and mineral-organic fertilizers. Those requirements are specified in the Act of 26 July 2000 concerning fertilizers and fertilizing (Dz. U. $\mathrm{Nr} 89$, poz. 991) with further changes ${ }^{4}$ and the Decree of the Minister of Agriculture and Rural Development of 1 June 2001 concerning the enactment of certain regulations of the act concerning fertilizers and fertilizing (Dz. U. $\mathrm{Nr} 60$, poz. 615) with further changes ${ }^{5}$.

\section{COMPOSTING INGREDIENTS}

The bio-utilization was conducted in five tests and the following food processing industry wastes were used: meat and bone pulp, past the sell-by date bakery and dairy

Table 1. The composition of particular tests

\begin{tabular}{|c|c|c|c|c|c|}
\hline \multirow{3}{*}{ MATERIAL } & PK-1 & PK-2 & PK-3 & PK-4 & PK-5 \\
\hline & $\begin{array}{c}\text { Tests mass: } \\
40.00 \mathrm{~kg}\end{array}$ & $\begin{array}{c}\text { Tests mass: } \\
49.44 \mathrm{~kg}\end{array}$ & $\begin{array}{c}\text { Tests mass: } \\
53.62 \mathrm{~kg}\end{array}$ & $\begin{array}{c}\text { Tests mass: } \\
70.60 \mathrm{~kg}\end{array}$ & $\begin{array}{c}\text { Tests mass: } \\
81.40 \mathrm{~kg}\end{array}$ \\
\hline & \multicolumn{5}{|c|}{ COMPOSITION [\%] } \\
\hline Meat and bone pulp & 50.0 & 40.4 & - & 28.3 & 24.6 \\
\hline Poultry manure & - & 24.9 & - & - & 34.4 \\
\hline Cattle manure & 37.5 & 22.2 & 56.5 & 28.3 & - \\
\hline Expired dairy products & - & 3.3 & 21.3 & 7.2 & 5.6 \\
\hline Expired bakery products & - & - & 10.3 & 7.8 & 8.4 \\
\hline Post-slaughter feathers & - & - & - & 14.2 & 12.3 \\
\hline Sawdust & 12.5 & 9.1 & 11.9 & 4.2 & 8.6 \\
\hline Straw & - & - & - & 2.8 & - \\
\hline \multirow[t]{3}{*}{ Fine brown coal } & - & - & - & 7.1 & 6.1 \\
\hline & \multicolumn{5}{|c|}{ Approximate $\mathrm{C}: \mathrm{N}: \mathrm{P}$ ratio } \\
\hline & $5.57: 0.65: 1.64$ & $8.20: 0.85: 0.30$ & $8.38: 0.27: 0.82$ & 12.01:1.13:0.75 & $18.04: 1.52: 1.40$ \\
\hline
\end{tabular}


products and post-slaughter feathers. As a comparison, poultry manure, cattle manure and their mix were used as a source of micro-organisms responsible for the biodegradation process. Also, straw and sawdust were added as an extra source of carbon and in order to give the right consistency . Furthermore, fine brown coal was added as an absorbent of odours and as a mineral enrichment of the final fertilizer. The ingredient proportions were picked in order to ensure that the $\mathrm{C}: \mathrm{N}: \mathrm{P}$ ratios were appropriate for the growth of biodegradating microorganisms and also for each test to be consistently adequate for composting in a rotational reactor.

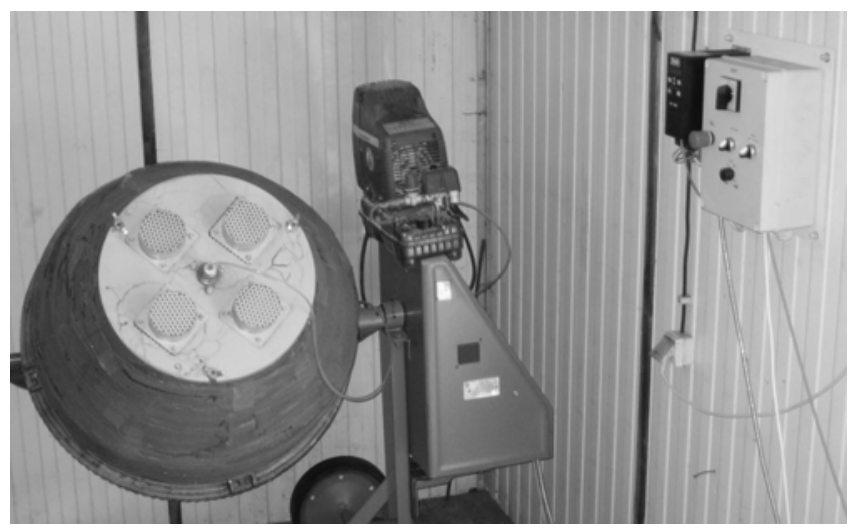

Figure 1. A rotational reactor with the air compressor and frequency converter

\section{EXPERIMENTAL ROTATIONAL REACTOR}

In order to conduct studies, an experimental rotational reactor was designed and constructed (Figure 1.). The device was made on the basis of a H095 concrete mixer of $\mathrm{V}=200 \mathrm{dm}^{3}$. The charging hole was fastened with a closure head equipped with four filters containing active carbon to absorb odours. To eliminate the losses of heat emitted during the composting process, the tumbler was covered with an additional layer of polyurethane foam. The reactor was equipped with a VLT 2800 frequency converter that made it possible to modify the reactor speed and sense of rotation. Furthermore, the tumbler was attached to an air compressor in order to create the conditions of intensive aeration inside the reactor's tumbler during the composting process.

\section{MICROBIOLOGICAL STUDIES}

The composting efficiency was evaluated based on the inactivation of selected strains of bacteria (Escherichia coli, Salmonella senftenberg $W_{775}$ i Enterococcus spp.) and eggs of invasive parasites (Ascaris suum). For this purpose, five specially prepared and adequately secured metal capsules with microbial carriers were added to every conducted test. Along with the composting progress and depending on the temperature inside the composted mass, the capsules with carriers were drawn out and stored at the temperature of $4-6{ }^{\circ} \mathrm{C}$ until the tests for microbiological inactivation have been performed.

\section{COMPOSTING PROCESS}

Composting, in the case of all the tests, was conducted at a reactor rotational speed of $4-7 \mathrm{rpm}$ until drawing out the last of the microbiological capsules. The temperature during the composting process was measured with a TB-Pt100-03A electronic meter. The temperature measured in the following composting cycles was a basic indicator for drawing out each of the capsules with microbial carriers and ipso facto for evaluating the efficiency of composting methods at every stage of composting. After the termination of each test, the newly-created fertilizer was treated with calcium oxide $(\mathrm{CaO})$ in order to raise the temperature of the composted mass suddenly and to eliminate any potential microbiological threat coming from an ineffective composting process. The resultant fertilizer was tested chemically and microbiologically by the Institute of Soil Science and Plant Cultivation in Puławy in order to determine its possible environmental usage.

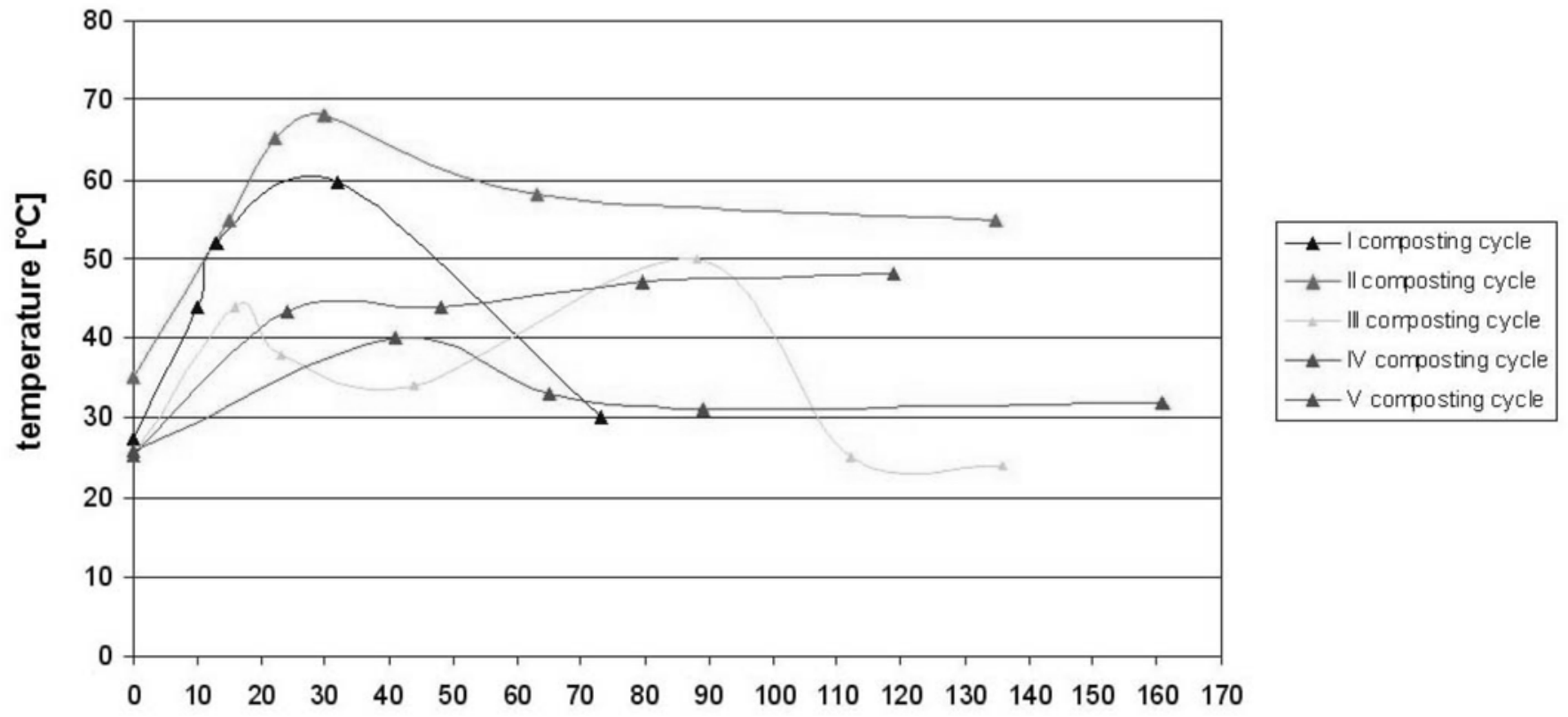

time [h]

Figure 2. The dependence of temperature by time in the following cycles of composting 


\section{RESULTS AND DISCUSSION}

The effectiveness of food industry waste composting is directly dependent on the temperature occurring during the process. It is the temperature that, except for being an obvious indicator of the intensiveness of biodegradation processes, conditions the efficiency of the inactivation of pathogens. Therefore, the composting temperature is the most basic parameter that shows the effectiveness of the presented methods of bioutilization. The results of temperature monitoring during the following composting cycles is presented in Figure 2.

The data presented in Figure 2. show clearly that the highest temperatures were stated during the composting cycles I and II. During the tests III, IV and V definitely lower temperatures were observed which resulted in the reduced effectiveness of the microbiological inactivation of pathogens in the composted mass. Those results are confirmed in the tests of the inactivation of selected strains of bacteria and eggs of invasive parasites.

In the case of composting cycle II (PK-2), where the highest temperatures were observed and also maintained for the longest period of time, it is already in the first microbiological carrier where full inactivation of eggs of invasive parasites Ascaris suum were identified . In the I composting cycle the measuring inactivation grade was impossible due to the destruction of carriers during the bio-utilization process. The high percentage of parasite eggs found in capsules drawn out from composting cycle IV during which the lowest temperatures were observed, clearly indicates the direct influence of this particular parameter on the efficiency of the microbiological inactivation process. The results for every composting cycle are presented in Table 2.

Table 2. The eggs of invasive parasites Ascaris suum inactivation rate [\%] in the following terms of the composting cycles

\begin{tabular}{|c|c|c|c|c|c|c|c|c|c|c|c|c|c|c|c|c|c|c|}
\hline Cycle II (PK-2) & \multicolumn{3}{|c|}{ Control } & \multicolumn{3}{|c|}{ Term 1} & \multicolumn{3}{|c|}{ Term 2} & \multicolumn{3}{|c|}{ Term 3} & \multicolumn{3}{|c|}{ Term 4} & \multicolumn{3}{|c|}{ Term 5} \\
\hline Time $[\mathrm{h}]$ & \multicolumn{3}{|c|}{0} & \multicolumn{3}{|c|}{15} & \multicolumn{3}{|c|}{22} & \multicolumn{3}{|c|}{30} & \multicolumn{3}{|c|}{63} & \multicolumn{3}{|c|}{135} \\
\hline $\mathrm{T}\left[{ }^{0} \mathrm{C}\right]$ & \multicolumn{3}{|c|}{-} & \multicolumn{3}{|c|}{55} & \multicolumn{3}{|c|}{65} & \multicolumn{3}{|c|}{68} & \multicolumn{3}{|c|}{58} & \multicolumn{3}{|c|}{55} \\
\hline Counting & I & II & III & $\mathrm{I}$ & II & III & $\mathrm{I}$ & II & III & $\mathrm{I}$ & II & III & 1 & II & III & $\mathrm{I}$ & II & III \\
\hline$\%$ invasive eggs & 95 & 94 & 95 & $\mathrm{nw}$ & nw & nw & $n w$ & nw & nw & nw & nw & nw & nw & 2 & nw & \multicolumn{3}{|c|}{\begin{tabular}{l|l} 
nw & nw \\
\end{tabular}} \\
\hline Cycle III (PK-3) & \multicolumn{3}{|c|}{ Control } & \multicolumn{3}{|c|}{ Term 1} & \multicolumn{3}{|c|}{ Term 2} & \multicolumn{3}{|c|}{ Term 3} & \multicolumn{3}{|c|}{ Term $4^{*}$} & & & \\
\hline Time [h] & \multicolumn{3}{|c|}{0} & \multicolumn{3}{|c|}{16} & \multicolumn{3}{|c|}{88} & \multicolumn{3}{|c|}{112} & \multicolumn{3}{|c|}{136} & & & \\
\hline $\mathrm{T}\left[{ }^{0} \mathrm{C}\right]$ & \multicolumn{3}{|c|}{-} & & 44 & & & 50 & & & 25 & & & - & & & & \\
\hline Counting & I & II & III & I & II & III & I & II & III & $\mathrm{I}$ & II & III & I & II & III & & & \\
\hline$\%$ invasive eggs & 93 & 95 & 96 & 13 & 15 & 14 & 20 & 16 & 17 & & $x$ & & 62 & 69 & 68 & & & \\
\hline Cycle IV (PK-4) & & Contr & & & Term & & & Term & & & Term 3 & & & erm 4 & & & & \\
\hline Time $[\mathrm{h}]$ & & 0 & & & 41 & & & 65 & & & 89 & & & 161 & & & & \\
\hline $\mathrm{T}\left[{ }^{0} \mathrm{C}\right]$ & & - & & & 40 & & & 33 & & & 31 & & & 32 & & & & \\
\hline Counting & 1 & II & III & $\mathrm{I}$ & II & III & $\mathrm{I}$ & II & III & 1 & II & III & 1 & II & III & & & \\
\hline$\%$ invasive eggs & 94 & 96 & 93 & 81 & 85 & 89 & 84 & 85 & 83 & 83 & 87 & 82 & 88 & 86 & - & & & \\
\hline Cycle V (PK-5) & & Contr & & & Term & & & Term & & & Term 3 & & & Term & & & erm 5 & \\
\hline Time [h] & & 0 & & & 24 & & & 48 & & & 79.5 & & & 119 & & & & \\
\hline $\mathrm{T}\left[{ }^{0} \mathrm{C}\right]$ & & - & & & 43 . & & & 43. & & & 47 & & & 48. & & & & \\
\hline Counting & 1 & II & III & I & II & III & I & II & III & I & II & III & I & II & III & I & II & III \\
\hline$\%$ invasive eggs & & & & 94 & 95 & 92 & 61 & 53 & 62 & 47 & 44 & 51 & 56 & 59 & 49 & 1 & 2 & 2 \\
\hline
\end{tabular}

\section{„X” no eggs carrier in the test}

- $\quad$ no eggs in suspension in the counting field under microscope

* test after treating with $\mathrm{CaO}$

nd none detected

Table 3. Bacteria counts [CFU/g compost] of Streptococcus, Escherichia coli and Salmonella species in the following carriers of the first composting cycle

\begin{tabular}{|c|c|c|c|c|c|c|}
\hline $\begin{array}{c}\text { Capsule drawning out } \\
\text { term }\end{array}$ & Term 0 & Term 1 & Term 2 & Term 3 & Term 4 & Term 5 \\
\hline $\begin{array}{c}\text { Time }[\mathrm{h}] \\
/ \\
\mathrm{T}\left[{ }^{\circ} \mathrm{C}\right]\end{array}$ & $\begin{array}{c}0 \mathrm{~h} \\
/ \\
-\end{array}$ & $\begin{array}{c}10 \mathrm{~h} \\
/ \\
44^{\circ} \mathrm{C}\end{array}$ & $\begin{array}{c}13 \mathrm{~h} \\
/ \\
52^{\circ} \mathrm{C}\end{array}$ & $\begin{array}{c}32 \mathrm{~h} \\
/ \\
59.5^{\circ} \mathrm{C}\end{array}$ & $\begin{array}{c}73 \mathrm{~h} \\
/ \\
30^{\circ} \mathrm{C}\end{array}$ & - \\
\hline Carrier & \multicolumn{6}{|c|}{ Streptococcus [CFU/g compost] } \\
\hline Suspension & $1.4 \times 10^{8}$ & $1.6 \times 10^{8}$ & $3.0 \times 10^{7}$ & $1.4 \times 10^{6}$ & $7.5 \times 10^{3}$ & - \\
\hline Meat cube $3 \times 3 \times 3$ & $1.6 \times 10^{8}$ & $1.4 \times 10^{8}$ & $4.5 \times 10^{7}$ & $1.4 \times 10^{6}$ & $1.4 \times 10^{4}$ & - \\
\hline Meat cube $5 \times 5 \times 5$ & $0.9 \times 10^{8}$ & $4.5 \times 10^{8}$ & $3.0 \times 10^{7}$ & $2.0 \times 10^{7}$ & $2.0 \times 10^{5}$ & - \\
\hline Carrier & \multicolumn{6}{|c|}{ Escherichia coli [CFU/g compost] } \\
\hline Suspension & $1.4 \times 10^{8}$ & $4.5 \times 10^{8}$ & $1.4 \times 10^{6}$ & $1.4 \times 10^{3}$ & 0 & - \\
\hline Meat cube $3 \times 3 \times 3$ & $2.5 \times 10^{8}$ & $3.0 \times 10^{8}$ & $7.5 \times 10^{4}$ & $1.4 \times 10^{2}$ & 0 & - \\
\hline Meat cube $5 \times 5 \times 5$ & $0.9 \times 10^{9}$ & $1.4 \times 10^{7}$ & $1.4 \times 10^{7}$ & $2.0 \times 10^{3}$ & 0 & - \\
\hline Carrier & \multicolumn{6}{|c|}{ Salmonella [CFU/g compost] } \\
\hline Suspension & $1.4 \times 10^{8}$ & $2.0 \times 10^{7}$ & $1.4 \times 10^{6}$ & $1.4 \times 10^{4}$ & $1.1 \times 10^{2}$ & - \\
\hline Meat cube $3 \times 3 \times 3$ & $1.4 \times 10^{7}$ & $0.9 \times 10^{6}$ & $1.5 \times 10^{6}$ & $1.4 \times 10^{2}$ & $0.7 \times 10^{2}$ & - \\
\hline Meat cube $5 \times 5 \times 5$ & $0.9 \times 10^{7}$ & $7.5 \times 10^{6}$ & $1.4 \times 10^{6}$ & $1.4 \times 10^{1}$ & 0 & - \\
\hline
\end{tabular}

- no carrier in the composted mass (incomplete sample) 
Table 4. Bacteria counts [CFU/g compost] of Streptococcus, Escherichia coli and Salmonella species in the following carriers of the second composting cycle

\begin{tabular}{|c|c|c|c|c|c|c|}
\hline $\begin{array}{c}\text { Capsule drawning out } \\
\text { term }\end{array}$ & Term 0 & Term 1 & Term 2 & Term 3 & Term 4 & Term 5 \\
\hline $\begin{array}{c}\text { Time }[\mathrm{h}] \\
/ \\
\mathrm{T}\left[{ }^{0} \mathrm{C}\right]\end{array}$ & $\begin{array}{c}0 \mathrm{~h} \\
/ \\
-\end{array}$ & $\begin{array}{c}15 \mathrm{~h} \\
/ \\
55^{\circ} \mathrm{C}\end{array}$ & $\begin{array}{c}22 \mathrm{~h} \\
/ \\
66^{\circ} \mathrm{C}\end{array}$ & $\begin{array}{c}30 \mathrm{~h} \\
/{ }^{\prime}{ }^{\circ} \mathrm{C}\end{array}$ & $\begin{array}{c}69 \mathrm{~h} \\
/ \\
58^{\circ} \mathrm{C}\end{array}$ & $\begin{array}{c}135 \mathrm{~h} \\
/ \\
55^{\circ} \mathrm{C}\end{array}$ \\
\hline Carrier & \multicolumn{6}{|c|}{ Streptococcus [CFU/g compost] } \\
\hline Suspension & $1.4 \times 10^{8}$ & $0.4 \times 10^{7}$ & $2.5 \times 10^{6}$ & 0 & 0 & 0 \\
\hline Meat cube $3 \times 3 \times 3$ & $1.4 \times 10^{8}$ & $4.5 \times 10^{8}$ & $1.6 \times 10^{5}$ & 0 & 0 & 0 \\
\hline Meat cube $5 \times 5 \times 5$ & $1.1 \times 10^{8}$ & $1.1 \times 10^{7}$ & $1.8 \times 10^{3}$ & 0 & 0 & 0 \\
\hline Carrier & \multicolumn{6}{|c|}{ Escherichia coli [CFU/g compost] } \\
\hline Suspension & $2.5 \times 10^{9}$ & $1.6 \times 10^{5}$ & $1.4 \times 10^{3}$ & 0 & 0 & 0 \\
\hline Meat cube $3 \times 3 \times 3$ & $2.0 \times 10^{8}$ & $7.0 \times 10^{4}$ & $1.1 \times 10^{2}$ & 0 & 0 & 0 \\
\hline Meat cube $5 \times 5 \times 5$ & $1.4 \times 10^{8}$ & $2.5 \times 10^{5}$ & $2.5 \times 10^{0}$ & 0 & 0 & 0 \\
\hline Carrier & \multicolumn{6}{|c|}{ Salmonella [CFU/g compost] } \\
\hline Suspension & $1.4 \times 10^{8}$ & $1.6 \times 10^{6}$ & 0 & 0 & 0 & 0 \\
\hline Meat cube $3 \times 3 \times 3$ & $1.1 \times 10^{9}$ & $2.5 \times 10^{7}$ & 0 & 0 & 0 & 0 \\
\hline Meat cube $5 \times 5 \times 5$ & $1.1 \times 10^{8}$ & $1.4 \times 10^{6}$ & $1.2 \times 10^{2}$ & 0 & 0 & 0 \\
\hline
\end{tabular}

Table 5. Bacteria counts [CFU/g compost] of Streptococcus, Escherichia coli and Salmonella species in the following carriers of the third composting cycle

\begin{tabular}{|c|c|c|c|c|c|c|}
\hline $\begin{array}{l}\text { Capsule drawning out } \\
\text { term }\end{array}$ & Term 0 & Term 1 & Term 2 & Term 3 & Term $4^{*}$ & Term $5^{*}$ \\
\hline $\begin{array}{l}\text { Time }[\mathrm{h}] \\
/ \\
\mathrm{T}\left[{ }^{0} \mathrm{C}\right]\end{array}$ & $\begin{array}{c}\mathrm{Oh} \\
/ \\
-\end{array}$ & $\begin{array}{c}16 \mathrm{~h} \\
/ \\
44^{\circ} \mathrm{C}\end{array}$ & $\begin{array}{c}88 \mathrm{~h} \\
/ \\
50^{\circ} \mathrm{C}\end{array}$ & $\begin{array}{c}112 \mathrm{~h} \\
2{ }^{\prime}{ }^{0} \mathrm{C}\end{array}$ & $\begin{array}{c}136 \mathrm{~h} \\
/\end{array}$ & - \\
\hline Carrier & \multicolumn{6}{|c|}{ Streptococcus [CFU/g compost] } \\
\hline Suspension & $1.4 \times 10^{8}$ & $7.0 \times 10^{8}$ & $1.1 \times 10^{7}$ & $7.0 \times 10^{8}$ & $1.4 \times 10^{8}$ & - \\
\hline Meat cube $3 \times 3 \times 3$ & $2.5 \times 10^{8}$ & $2.0 \times 10^{8}$ & $2.0 \times 10^{7}$ & $1.4 \times 10^{7}$ & $1.4 \times 10^{8}$ & - \\
\hline Meat cube $5 \times 5 \times 5$ & $7.0 \times 10^{8}$ & $1.4 \times 10^{8}$ & $2.5 \times 10^{8}$ & $1.1 \times 10^{7}$ & $2.0 \times 10^{8}$ & - \\
\hline Carrier & \multicolumn{6}{|c|}{ Escherichia coli [CFU/g compost] } \\
\hline Suspension & $2.0 \times 10^{8}$ & $1.1 \times 10^{7}$ & $4.5 \times 10^{4}$ & $0.9 \times 10^{2}$ & - & - \\
\hline Meat cube $3 \times 3 \times 3$ & $1.4 \times 10^{8}$ & $3.0 \times 10^{8}$ & - & 0 & - & - \\
\hline Meat cube $5 \times 5 \times 5$ & $2.0 \times 10^{8}$ & $1.4 \times 10^{7}$ & $2.5 \times 10^{3}$ & 0 & - & - \\
\hline Carrier & \multicolumn{6}{|c|}{ Salmonella [CFU/g compost] } \\
\hline Suspension & $2.5 \times 10^{8}$ & $7.0 \times 10^{7}$ & $1.1 \times 10^{3}$ & $1.4 \times 10^{4}$ & $0.7 \times 10^{2}$ & - \\
\hline Meat cube $3 \times 3 \times 3$ & $4.0 \times 10^{8}$ & $1.4 \times 10^{6}$ & $2.0 \times 10^{4}$ & $1.4 \times 10^{2}$ & $1.1 \times 10^{2}$ & - \\
\hline Meat cube $5 \times 5 \times 5$ & $2.0 \times 10^{8}$ & $2.5 \times 10^{5}$ & 0 & $7.0 \times 10^{2}$ & $1.4 \times 10^{2}$ & - \\
\hline
\end{tabular}

* test after treating with $\mathrm{CaO}$

- no carrier in the composted mass (incomplete sample)

The results of the parasites egg inactivation and their direct correlation with the temperature observed in the composting cycles is reflected in the results of microbiological tests presented in Tables 3. - 7. on the presence of bacteria strains Escherichia coli, Salmonella senftenberg $W_{775}$ and Enterococcus spp. In the case of II composting cycle, full inactivation was stated in a third capsule drawn out during the process. Such an efficiency of the composting process was not observed in any other of the conducted tests. Even in the first cycle, in which for a short period of time relatively high temperatures were observed, only inactivation of $E$. coli in the fourth drawn out capsule was identified. In the rest of the cycles, even if inactivation of some strains was observed in a few carriers, then those strains appeared again in the following capsules of the same cycle.

Due to the same methodology being used in every conducted test, the reason for such a discrepancy in the microbiological results for each composting trial may be caused by differences in the compositions of each composting cycle. The reason for the effectiveness of the first two tests might have been a considerable additive of meat and bone pulp as a source of microbiologically available carbon and nitrogen. Definitely, the best results, in terms of temperature achieved during the process and pathogen inactivation in the second cycle, might have been caused by the addition of the past their sell-by date dairy products and mixed both the poultry and cattle manure.

Notable is also the fact that in the III cycle, without the addition of meat and bone pulp, higher temperatures of the composting mass were registered compared to cycles IV and V. It was most probably caused by the addition of the post-slaughter feathers to the tests IV and V. Feathers, due to their keratine structure, are a material which is difficult to biodegrade ${ }^{6}$ and as such is a poor source of microbiologically available carbon and nitrogen.

The above research shows that with the proper composition of the composting batch and the right proportions of materials used, the presented biodegradation technology might be an efficient method of food industry waste management.

An additional confirmation of this conclusion is a positive opinion of the Institute of Soil Science and Plant 
Table 6. Bacteria counts [CFU/g compost] of Streptococcus, Escherichia coli and Salmonella species in the following carriers of the fourth composting cycle

\begin{tabular}{|c|c|c|c|c|c|c|}
\hline $\begin{array}{l}\text { Capsule drawning out } \\
\text { term }\end{array}$ & Term 0 & Term 1 & Term 2 & Term 3 & Term 4 & Term $5^{*}$ \\
\hline $\begin{array}{l}\text { Time }[\mathrm{h}] \\
/ \\
\mathrm{T}\left[{ }^{\circ} \mathrm{C}\right]\end{array}$ & $\begin{array}{c}\mathrm{Oh} \\
1 \\
-\end{array}$ & $\begin{array}{c}41 \mathrm{~h} \\
/ \\
40^{\circ} \mathrm{C}\end{array}$ & $\begin{array}{c}65 \mathrm{~h} \\
1 \\
33^{\circ} \mathrm{C}\end{array}$ & $\begin{array}{c}59 \mathrm{~h} \\
/ \\
31.2^{\circ} \mathrm{C}\end{array}$ & $\begin{array}{c}161 \mathrm{~h} \\
/ \\
32^{\circ} \mathrm{C}\end{array}$ & - \\
\hline Carrier & \multicolumn{6}{|c|}{ Streptococcus [CFU/g compost] } \\
\hline Suspension & $1.4 \times 10^{8}$ & $3.0 \times 10^{8}$ & $1.4 \times 10^{8}$ & $1.1 \times 10^{7}$ & $1.4 \times 10^{6}$ & $1.1 \times 10^{5}$ \\
\hline Meat cube $3 \times 3 \times 3$ & $1.4 \times 10^{9}$ & $2.5 \times 10^{8}$ & $1.1 \times 10^{8}$ & $1.6 \times 10^{7}$ & $2.5 \times 10^{7}$ & - \\
\hline Meat cube $5 \times 5 \times 5$ & $1.1 \times 10^{8}$ & $1.4 \times 10^{8}$ & $1.1 \times 10^{7}$ & $4.5 \times 10^{8}$ & $1.8 \times 10^{8}$ & $2.3 \times 10^{6}$ \\
\hline Carrier & \multicolumn{6}{|c|}{ Escherichia coli [CFU/g compost] } \\
\hline Suspension & $1.1 \times 10^{9}$ & $2.5 \times 10^{8}$ & $1.4 \times 10^{7}$ & $1.6 \times 10^{7}$ & $2.5 \times 10^{2}$ & $2.0 \times 10^{2}$ \\
\hline Meat cube $3 \times 3 \times 3$ & $4.5 \times 10^{8}$ & $1.5 \times 10^{7}$ & $2.5 \times 10^{8}$ & $1.8 \times 10^{6}$ & $2.8 \times 10^{5}$ & $1.1 \times 10^{3}$ \\
\hline Meat cube $5 \times 5 \times 5$ & $9.5 \times 10^{8}$ & $7.7 \times 10^{8}$ & $1.4 \times 10^{7}$ & $2.0 \times 10^{6}$ & $2.7 \times 10^{4}$ & - \\
\hline Carrier & \multicolumn{6}{|c|}{ Salmonella [CFU/g compost] } \\
\hline Suspension & $1.4 \times 10^{8}$ & $2.5 \times 10^{8}$ & $1.6 \times 10^{6}$ & $1.1 \times 10^{7}$ & $2.5 \times 10^{7}$ & - \\
\hline Meat cube $3 \times 3 \times 3$ & $4.5 \times 10^{8}$ & $7.0 \times 10^{7}$ & $1.8 \times 10^{8}$ & $2.8 \times 10^{6}$ & $1.4 \times 10^{7}$ & - \\
\hline Meat cube $5 \times 5 \times 5$ & $1.6 \times 10^{8}$ & $2.8 \times 10^{8}$ & $2.3 \times 10^{7}$ & $1.4 \times 10^{7}$ & $1.4 \times 10^{3}$ & - \\
\hline
\end{tabular}

* test after treating with $\mathrm{CaO}$

- no carrier in the composted mass (incomplete sample)

Table 7. Bacteria counts [CFU/g compost] of Streptococcus, Escherichia coli and Salmonella species in the following carriers of the fifth composting cycle

\begin{tabular}{|c|c|c|c|c|c|c|}
\hline $\begin{array}{l}\text { Capsule drawning out } \\
\text { term }\end{array}$ & Term 0 & Term 1 & Term 2 & Term 3 & Term 4 & Term $5^{*}$ \\
\hline $\begin{array}{l}\text { Time }[\mathrm{h}] \\
/ \\
\mathrm{T}\left[{ }^{0} \mathrm{C}\right]\end{array}$ & $\begin{array}{c}0 \mathrm{~h} \\
/ \\
-\end{array}$ & $\begin{array}{c}24 \mathrm{~h} \\
/ \\
43.5^{\circ} \mathrm{C}\end{array}$ & $\begin{array}{c}48 \mathrm{~h} \\
/ \\
43.8^{\circ} \mathrm{C}\end{array}$ & $\begin{array}{c}99.5 \mathrm{~h} \\
/ \\
47^{\circ} \mathrm{C}\end{array}$ & $\begin{array}{c}119 \mathrm{~h} \\
/ \\
48.1^{\circ} \mathrm{C}\end{array}$ & - \\
\hline Carrier & \multicolumn{6}{|c|}{ Streptococcus [CFU/g compost] } \\
\hline Suspension & $1.4 \times 10^{9}$ & $1.4 \times 10^{9}$ & $1.4 \times 10^{9}$ & $2.0 \times 10^{4}$ & $3.0 \times 10^{4}$ & $3.5 \times 10^{2}$ \\
\hline Meat cube $3 \times 3 \times 3$ & $1.4 \times 10^{9}$ & $1.4 \times 10^{9}$ & $1.4 \times 10^{9}$ & $1.4 \times 10^{6}$ & $1.4 \times 10^{6}$ & 0 \\
\hline Meat cube $5 \times 5 \times 5$ & $1.4 \times 10^{9}$ & $1.4 \times 10^{9}$ & $1.4 \times 10^{9}$ & $1.4 \times 10^{7}$ & $1.4 \times 10^{9}$ & $3.0 \times 10^{1}$ \\
\hline Carrier & \multicolumn{6}{|c|}{ Escherichia coli [CFU/g compost] } \\
\hline Suspension & $1.4 \times 10^{9}$ & $9.5 \times 10^{4}$ & $9.5 \times 10^{3}$ & 0 & $1.1 \times 10^{2}$ & $2.5 \times 10^{4}$ \\
\hline Meat cube $3 \times 3 \times 3$ & $1.4 \times 10^{9}$ & $3.0 \times 10^{6}$ & - & 0 & 0 & 0 \\
\hline Meat cube $5 \times 5 \times 5$ & $1.4 \times 10^{9}$ & $1.4 \times 10^{9}$ & $6.5 \times 10^{2}$ & 0 & 0 & 0 \\
\hline Carrier & \multicolumn{6}{|c|}{ Salmonella [CFU/g compost] } \\
\hline Suspension & $1.4 \times 10^{9}$ & $1.4 \times 10^{9}$ & $1.4 \times 10^{9}$ & 0 & $4.5 \times 10^{4}$ & 0 \\
\hline Meat cube $3 \times 3 \times 3$ & $1.4 \times 10^{9}$ & $1.4 \times 10^{9}$ & $4.0 \times 10^{4}$ & 0 & 0 & 0 \\
\hline Meat cube $5 \times 5 \times 5$ & $1.4 \times 10^{9}$ & $1.4 \times 10^{9}$ & $2.5 \times 10^{4}$ & 0 & 0 & 0 \\
\hline
\end{tabular}

* test after treating with $\mathrm{CaO}$

- no carrier in the composted mass (incomplete sample)

Cultivation in Puławy in respect of a possible environmental usage of the final products of composting.

\section{CONCLUSIONS}

1. Differences of temperatures observed during the conducted composting tests directly influenced the efficiency of pathogens inactivation in the batches tested.

2. Only the conditions noted in the second composting cycle led to full inactivation of pathogens in microbial carriers.

3. The composition of the composting batches has a key-meaning for the bio-utilization process. Major participation of meat and bone pulp in composting composition had a strong influence on the efficiency of the biodegradation process. On the other hand, the addition of the difficult-to-biodegrade material, such as the post-slaughter feathers, lowered the effectiveness of the process.

4. The composting method presented in this paper might be a safe and economically justified technology for food industry waste management.
5. The Institute of Soil Science and Plant Cultivation in Puławy expressed a positive opinion on the fertilizing preparations in respect of their possible environmental usage based on the requirements for organic and mineralorganic fertilizers specified in the Act of 26 July 2000 concerning fertilizers and fertilizing (Dz. U. Nr 89, poz. 991) with further changes and the Decree of Minister of Agriculture and Rural Development of 1 June 2001 concerning the enactment of some regulations of the act concerning fertilizers and fertilizing (Dz. U. Nr 60, poz. $615)$ with further changes.

The results presented in this paper were obtained within the purposeful project no 6T092005C/06541 „Sludge and organic wastes utilization technology development" financed by Ministry of Science and Higher Education

\section{LITERATURE CITED}

1. Shaub, S.M. \& Leonard J.J., (1996). Composting: An alternative waste management option for food processing industries, Trends in Food Science \& Technology, 7, 263 - 268. 
2. Rosik-Dulewska, Cz., (2006). Podstawy gospodarki odpadami, Wydawnictwo Naukowe PWN, Warszawa.

3. Paluszak, Z., (2007). Raport z badań mikrobiologicznej oceny metody kompostowania odpadów rzeźnianych oraz innych odpadów z przemystu spożywczego $z$ dalsza możliwościa wykorzystania ich $w$ rolnictwie, na podstawie inaktywacji wybranych szczepów bakterii oraz jaj inwazyjnych pasożytów, UT-P Bydgoszcz.

4. Ustawa o nawozach i nawożeniu z dnia 26 lipca $2000 \mathrm{r}$. (Dz. U. Nr 89, poz. 991) z późniejszymi zmianami.

5. Rozporządzenie Ministra Rolnictwa i Rozwoju Wsi z dnia 1 czerwca 2001 r. w sprawie wykonania niektórych przepisów ustawy o nawozach i nawożeniu (DzU nr 60, poz. 615) z późniejszymi zmianami.

6. Grazziotin, A., Pimentem, F.A., de Jong, E.V. \& Brandelli, A., (2006). Nutritional improvement of feather protein by treatment with microbial keratinase, Animal Feed Science and Technology, 126, 135 - 144. 